\title{
Jean-Luc Nancy og kristendommens selvafvikling
}

\author{
LARS ALBINUS
}

ENGLISH ABSTRACT: The aim of this article is, on the one hand, to present JeanLuc Nancy's thought about the deconstruction of Christianity and, on the other, to suggest its possible significance for the general study of religion. According to Nancy, who belongs to a line of thinkers spanning from Nietzsche through Heidegger to Derrida, Christianity initiated the loss of meaning (sens) which permeates the contemporary (notion of) the world. Yet, at the same time, Christianity opens an alterity in the midst of the world owing to the pre-Christian roots of Christ as a redeemer of this world. In a wider perspective, Nancy locates the emergence of religion in a first distinction (as between light and shade) from which the order of the world evolves. In modernity, however, this distinction, or 'the divine' as such, only greets us in passing, reflecting the relations between all things of the world which thus salute one another in mutual exposition, that is, in their ex-istence.

DANSK RESUME: Hensigten med denne artikel er på den ene side at præsentere Jean-Luc Nancys tanker omkring kristendommens dekonstruktion og på den anden side at antyde hans mulige betydning for en religionsvidenskabelig faghorisont. For Nancy, der specielt står $i$ arv til tænkere som Nietzsche, Heidegger og Derrida, danner kristendommen baggrund for det betydningstab, der kendetegner en moderne (opfattelse af) verden. På samme tid vidner kristendommen imidlertid om den før-kristne Kristus, der som en forløser af denne verden har åbnet en 'andethed' midt $i$ den. I et videre perspektiv ser Nancy al religions tilblivelse $i$ en forste spaltning (som mellem lys og skygge), hvorfra verden kan fremstå som orden. I moderniteten optræder denne spaltning, eller det guddommelige som sådan, alene som en forbipasserende 'frelse' (salut) eller 'hilsen' (salut), der reflekterer den måde, hvorpå alt $i$ verden hilser hinanden i gensidig eksponering, dvs., eks-istens.

KEYWORDS: Jean-Luc Nancy; deconstruction; Christianity; alterity; divine distinction; transimmanens. 
God can only be present in creation under the form of absence Simone Weil, Gravity and Grace

\section{Indledning}

Nærværende artikel har til formål at præsentere den nulevende franske filosof JeanLuc Nancys tænkning ${ }^{1}$ som en religionsfilosofisk tænkning og dertil give et bud på, hvorledes dens aktuelt indflydelsesrige, men også i nogen grad esoteriske, perspektiv kan relateres til en generel religionsvidenskabelig horisont. At sætte Nancy ind i en religionsfilosofisk sammenhæng kræver først og fremmest, at man får hold på hans idé om kristendommen som religion. På den ene side ser han, som Nietzsche, en religiøs verdensforflygtigelse som ophav til nihilisme, dvs. at verden tømmes for betydning, på den anden side ser han også i religionen en måde at 'åbne' verden på, som stadig vedkommer tænkningen (og hvormed tænkningen også omvendt stadig har noget at sige den religiøse tradition). Nancys tankeunivers spreder sig i øvrigt vidt med æstetisk-filosofiske kerneinteresser i kroppen og dens nøgenhed, berøring, lytten og seen, og svarende hertil, billedkunst, musik og film. Hans bøger om kristendommens dekonstruktion, der i nogen grad løber parallelt med vennen og kollegaen Giorgio Agambens Homo Sacer-projekt, gør imidlertid et grundlæggende mellemværende mellem teologi og filosofi til sin hovedsag. Hvor Agamben primært følger i Walter Benjamins kulturkritiske og Michel Foucaults genealogiske fodspor, lægger Nancy sig i forlængelse af Heidegger og Derrida m.h.p. det meningstab, de tillægger moderniteten. ${ }^{2}$ Nancys interesse for den religiøse tradition handler imidlertid ikke om at pynte på dette tab. 'Det drejer sig ikke om at genmale himlen', som han skriver, men 'om at åbne jorden, dunkel, hård og tabt i rummet' $(2005,1)$. $^{3}$ At Nancy tilsyneladende spiller ud med en filosofisk handlingsplan, betyder dog ikke, at han har i sinde at tale på vegne af en kristen tradition. Tværtimod forstår han den åbning, han har i sigte, som en åbning, der følger af kristendommens eget selvafviklende forhold til sig selv og verden. Dermed gør han sig samtidig til talsmand for en generel forståelse af religion som tilsynekomsten af en deling i verden, der skaber et immanent forhold til en anden verden (mere herom nedenfor). Ikke overraskende tager han i den forbindelse afsæt i Nietzsches opgør med kristendommen.

1 Jean-Luc Nancy (1940-) har været ansat ved universitetet i Strassbourg siden 1968 og tillige optrådt som gæsteprofessor ved universiteter verden over, samt som kulturattaché for det franske udenrigsministerium. Han har skrevet talrige bøger om fremtrædende filosoffer, samt værker om religion, litteratur, kunst og film.

2 Der kastes i den forbindelse væsentlige sideblikke til Friedrich Nietzsche, Georges Bataille, Maurice Blanchot, Gilles Deleuze og Gérard Granel.

3 Alle oversættelser af Nancy er mine egne. 


\section{Fra Nietzsche til Nancy}

Nietzsches revolutionerende og lidenskabelige kritik af den kristne traditions selvforståelse var til dels båret af et selvpromoverende kulturopgør. Jeg vil mene, at religionsvidenskabens generelle tilgang til religion er båret af en lignende prætention om demaskering, dog uden samme patos. Den franske filosof Paul Ricoeur har påpeget, at kulturkritikken hos Marx, ${ }^{4}$ Nietzsche og Freud var drevet af en mistankens hermeneutik, og det er oplagt at placere udviklingen af sammenlignende religionsstudier i samme spor. Om baggrunden for denne fælles tendens hævdede en anden fransk filosof, Michel Foucault, at de rammer for viden (episteme), som i 1800tallet betød, at den menneskelige fornuft trådte i centrum for erkendelsen af sig selv, var begyndt at vige for en opdagelse af 'det ubevidste'. Oplysningens ubønhørlige krav til selverkendelse, som ifølge Nietzsche var en konsekvens af den kristne vilje til sandhed, var tilsyneladende endt med at drive fornuften ud af eget hus. Man anede allerede i midten af det 19. århundrede, at naturvidenskaben kunne åbne for indsigter i menneskets natur, som religionen blot havde dæmoniseret og filosofien afvist som uværdige for menneskets rationelle selvforståelse. Mennesket måtte med andre ord blive fremmed for sig selv for at kunne komme til kendskab om sig selv. Som Foucault (1999, 85 f.) konstaterede, indebar Guds død derfor også menneskets død, forstået som ophævelsen af den Gudsbilledlighed, en skolastisk fornuft havde værnet om gennem århundreder. Den oplyste idealismes forsøg på at bevare og endog styrke fornuften selv, hinsides den guddommelige autoritets detronisering, begyndte ligeledes at få noget spøgelsesagtigt over sig. Det ulegemlige ved fornuften, der hidtil havde været dens pant på evigheden, var vendt tilbage for at hjemsøge den. En fornemmelse af noget hult og selvovervurderende ledsagede troen på en ny begyndelse. Mistanken om skjulte kræfter, som ikke vidnede om Djævelens indflydelse, men om den menneskelige natur selv, tog næring til sig fra en affortryllelse af verden. ${ }^{5}$ Kroppen og dens gang på jorden gav genlyd fra en naturvidenskabelig erkendelseshorisont, og det smittede af på åndsvidenskaberne. Den biologiske livsvilje konkurrerede med forestillingen om sjælens udødelighed som centrum for menneskets forståelse af sig selv. Det, der fremhævede mennesket blandt andre levende væsner, var først og fremmest den måde, hvorpå det det formede sin verden gennem sprog, symboler og ideer. Grunden var dermed gødet for en psykologisk, antropologisk og historisk forståelse af religion. I forsøget på at forstå menneskehedens kulturelle mangfoldighed gjaldt det ikke først og fremmest om at tage de enkelte symboler og myter bogstaveligt, men om at forstå en bagvedliggende tænkemåde, at gøre sig et begreb om selve det symbolskabende i menneskets natur.

Hvor romantikken fokuserede på den kreative side af åndens virke, slog mistanken om verdensforflygtigelse igennem i den efterfølgende periode. Nietzsches kristendomskritik er et godt eksempel. Han fremmanede således et diffamerende bil-

4 Faktisk kunne Marx $(2000,51)$ allerede i 1844 hævde, at 'kritikken af religionen' for Tysklands vedkommende 'i det væsentlige er afsluttet'.

5 Begrebet om en 'affortryllelse' (Entzauberung) af verden stammer fra Max Weber (2009, I, bind 17), mens Marcel Gauchet (1997) specifikt taler om kristendommens affortryllelse (démystification). 
lede af, hvorledes de kristne i troen på en almægtig Gud underkastede sig en moral, der bød dem at leve det jordiske liv med henblik på en anden og bedre verden. I virkeligheden, hævdede Nietzsche, var de drevet af et uerkendt nag (ressentiment) og søgte at skaffe sig hævn over alle dem, der vakte deres forargelse ved at stille sig tilfreds med en dennesidig tilværelse.

Nietzsches generelle pointe var, at de forestillinger, menneskene $i$ almindelighed og religiøse mennesker i særdeleshed gør sig om meningen med livet, ikke stammer fra en meningsfuld virkelighed selv, men slet og ret fra et behov for mening. Schopenhauer havde netop åbnet Nietzsches øjne for, at verden fremtræder for os i kraft af vores vilje, og at en i sig selv meningsløs lidelse må omtolkes for at give mening. Men hvor det for Nietzsche drejede sig om at påtage sig lidelsen som naturlig omkostning ved livet, kunne han samtidig konstatere, at han var barn af en kultur, som forsagede naturen i moralens skinhellige navn. Som Foucault (2006, 326 ff.) har forsøgt at vise, lå humanvidenskabernes empiriske forklaringshorisont under for en tilsvarende illusion om, at menneskelivet skulle kunne beherskes gennem forklaring. Viljen til sandhed var blevet blind for sig selv som vilje. I jagten på en afsløring af menneskelige illusioner havde den overset den illusion, den selv hvilede på, nemlig at kendsgerninger som sådan skulle være i stand til at slukke moderne menneskers tørst efter mening.

Uden at ville råde bod på det meningsunderskud, som gør sig gældende i modernitetens erfaringsverden (og som videnskaben ikke har vist sig i stand til at udfylde), retter Jean-Luc Nancy sin opmærksomhed mod kristendommen, eller rettere: som filosof afficeres han stadig af den tilsigelse, der ligger i den kristne forkyndelse. Nancys grundlæggende tanke er, at kristendommen fra begyndelsen af har åbnet en andethed (alteriet) i verden selv, hvorfor nihilismen - den totale værditømning ikke er langtidsvirkningen af en eskatologisk frelsestanke (hvor al værdi flyttes ud af verden og over i håbet om en kommende frelse), men selve det kristne indbegreb af den verden, vi lever i. Nietzsches 'afsløring' af kristendommens iboende livsfornægtelse har derfor først og fremmest betydning - for Nancy - som 'selvafsløring', dvs. ikke som teori, men alene ved at kommunikere en personlig erfaring af 'dekadence' $(2008,75)$. Nietzsche erkendte nemlig en indpodet fremmedhed over for den livsvilje, der brændte i ham. Gennem erfaringen af sin egen tids degeneration øjnede han samtidig den oprindelige dekadence, hvormed 'den eneste sande kristne', Kristus selv, levede sit liv, som om det ikke var af denne verden.

Nietzsche taler i værket Antikrist om Kristus som 'den store symbolist', der forvandlede den ydre verden til en indre virkelighed, hvor alle forskelle ophævedes i ubetinget kærlighed (1999, II, 1196 §34). Den sande, evige verden, hvor al lidelse, selv dødens vilkår, er overvundet, er intet andet end det himmerige, der forkyndes med udsagnet 'Guds rige er inden i jer' (ibid. §30). Dog stod det kun til Jesus selv, menneskesønnen, at vende den ydre verden om i et indre lys, i hvis skær alle forskelle forsvandt (for så vidt nemlig som han tog menneskenes synder på sig). Med kristendommen som kirke, dvs. med præsterne og menigheden, vendte skyggerne forskellene - tilbage, og den evighed, Kristus forkyndte (og rummede i sig), for- 
svandt ud af verden som et løfte om et liv efter døden, samt et regnskab, der skulle gøres op på dommedag.

At Nancys tænkning 'berøres' af en kristen $\operatorname{arv}^{6}$, eller af en 'tillukket verdens genåbning', står på ingen måde i modsætning til den forbandelse, Nietzsche slynger imod den i Antikrist. Tværtimod griber Nancy tilbage til Kristus-skikkelsen selv i betydningen 'Ante-krist', nemlig som den verdensforløser, der går forud ('ante') for kristendommens Kristus, og som atter skal overvinde denne (2008, 77). Men hvori består da den forløsning, som Nietzsche i Nancys øjne tilskriver den oprindelige Kristus? Svaret er, at Kristus og kun Kristus kan ses som legemliggørelsen af 'erfaringen af hvad der ikke er af denne verden, uden af den grund at være en anden verden' (op.cit. 78; ligeledes 2005, 120). Den kristne frelse er således en frelse 'fra andre verdener'; 'den genopretter (remet) os til verden og sætter (met) fornyet ind i verden, som ny' (ibid.). Kristendommen taler altså ikke til Nancy som et budskab om frelse fra denne verden eller som et løfte om en anden og bedre verden, men tværtimod som udtryk for et meningstab, der åbner verden selv på en ny - eller fornyet - måde. Med Guds død, pointerer han, forstummer spørgsmålet om selve repræsentationens mulighed $(2008,75)$. Hvad Nietzsche forstod, var, at selve den væren, som Gud tidligere repræsenterede, nu er bragt til at skælve (op.cit. 76). Værensnærværet - præsensen - har ikke længere en grund, den kan bryde fri fra, men heller ikke en grund, den kan trække sig tilbage i. 'Præsensen befinder sig, vaklende', som Nancy formulerer det, 'på grænsen til at komme til syne i en verden, hvor der ikke længere er noget brud eller nogen åbning mellem væren og skin' (ibid.). Og som han tilføjer i paradoksets form: 'Eftersom der ikke længere gives et brud mellem væren og skin, er der ikke længere nogen anden væren end dette brud' (ibid.).

Med lidt andre ord kan man sige, at Nancy bekræfter den skepticisme, som i moderniteten har afløst forestillingen om en Guds- og fornuftsgaranteret virkelighed. Eftersom denne verdens tilskikkelser ikke længere hævdes at have rod i en højere, nødvendig væren, kan de kun forstås som tilfældigheder, der har tømt verden for meningsindhold. Ingen handlinger eller begivenheder kan længere forbindes med en ubetinget målsætning. De værdier, der stod skrevet i Guds, og siden i menneskehedens navn, har opløst sig i vilkårlige præferencer. Nihilismen har dermed realiseret sit inderste potentiale. Mens Nietzsche på dette punkt ville tænke sig fri af den kristne tradition, han betragtede som hul og udlevet, ser Nancy med anderledes positive øjne på det forhold, at den kristne forkyndelse deler skæbne med den verden, den har tømt for mening. Paradokset er nemlig, at evangeliet ved at

6 Jeg har valgt på selve beskrivelsesniveauet at inddrage den intime forbindelse mellem 'mening' (sens) og 'sans' (sens), som Nancy gør til en pointe ved at knytte 'betyde', 'berøre' og 'røre' tæt sammen. Således skriver han $\mathrm{fx}$, at det drejer sig om at forstå 'verdens mening' (le sens du monde) ud fra 'selve dens konkrethed [concrétude], således som vores eksistens berører den og berøres af den, i alle mulige betydninger [les sens]' $(1993,22)$. Endvidere påpeger han eksemplificerende, at 'betydningen [le sens] af ordet "betydning" ['sens'] gennemløber [traverse] de fem sanser [sens], samt retningssansen [le sens directionel], den almindelige sunde fornuft [le sens commun], den semantiske betydning [le sens sémantique], forudseenheden [le sens divinatoire], følelsen [le sentiment], den moralske sans [le sens moral], den praktiske sans [le sens pratique], den æstetiske sans [le sens esthétique]' (1993, 30). 
udtømme sig selv i verden peger på en immanent åbenhed, som ikke er af denne verden. 'Hvis kristendommen i alt væsentligt er kerygmatisk eller evangelisk', som han skriver, 'drejer det sig om at forsøge at koncentrere vores blik på selve hjertet $\mathrm{i}$ forkyndelsen, det levende, evangeliske hjerte i kristendommen, for at passere det punkt, hvor Nietzsche stod af' (2008, 150). Nancy hævder altså, at den verden, i hvilken Gud ikke længere er til, har lukket sig om sig selv. Men det er kun ansatsen til den egentlige pointe, nemlig at det meningstab, der følger af, at verden har hegnet sig ind bag repræsentationen af sig selv, bør modsvares af en ny lydhørhed. Ifølge Nancy er tiden således atter moden til at lade sig berøre af en åbning i verden, som ikke er af denne verden. Kristendommens dekonstruktion af sig selv, der uvægerligt indebærer, at Gud og det evige liv har opløst sig selv som fantasmer, betyder altså ikke, at historien er fortalt til ende. 'Det er ikke længere relevant i dag', hævder Nancy, 'at angribe eller forsvare kristendommen', men tværtimod at forstå betydningen af den selvoverskridelse, som er særegen for den, måske ovenikøbet 'dens dybeste tradition' (op.cit. 141).

Det græske begreb homoousia, der betyder 'af samme natur', dækker over en kristologisk tro på overensstemmelsen mellem Faderen og Sønnen. Dermed var der skabt afstand til den førkristne ontologi, som udledte overensstemmelsen (homoiosis) mellem forskellige tings væren (ousia) af en ren fornuftsindsigt. I inkarnationen fik alting en ny betydning: Ikke alene havde Gud vist sig i menneskesønnens natur, dvs. i selve menneskets essens, men i denne essens havde en væren dermed åbnet sig, som gjorde verden selv til noget fremmedartet. Med denne fremmedgørelse trådte intethedens betydning, repræsentationens iboende tomhed, efterhånden frem i menneskets forhold til sig selv og sin omverden. I stedet blev mennesket ladt tilbage med et håb om parousiaen, sønnens og betydningens genkomst (op.cit. 151). Den udsættelse af frelsen, der således bliver et billede på kristendommens egen skæbne, dens selvafvikling og betydningstømning, er dermed i Nancys optik et andet udtryk for 'betydningens generelle skæbne', nemlig dens spatio-temporale henstand (på én gang deponeret og udsat - med merbetydningen 'sat ud' - i en selvtillukket verden).

\section{Inspirationen fra Heidegger og Derrida}

Et andet begreb for betydningens udsættelse er 'différance', Jacques Derridas term for en 'forskelsætten', der udskyder værensnærværets sproglige samtidighed med sig selv $(1967,38) .{ }^{7}$ Begrebet skal forstås i direkte relation til hans begreb om dekonstruktion, nemlig den på én gang nedbrydende og genopbyggende fremdragelse af de fortielser i en given tekst (eller tankegang), som dens betydning hviler på (de mulige betydningers 'umulighedsbetingelser', som han også formulerer det). Ikke

7 Nancy gengiver Derridas begreb om 'différance' som 'det at komme uden at ankomme, denne identitet hvis præsens [présence] er forrang [préséance] og forekommenhed [prévenance] over for sig selv' $(1993,27)$ og formulerer for sit eget perspektivs vedkommende 'différance' (som han i øvrigt ikke tillægger en særlig begrebslig status) som 'betydningens index [l'index du sens] som fraværende betydning uden dennes frarøvelse [sans privation de sens]' $(1993,57)$. 
for ingen ting taler også Nancy om kristendommens 'dekonstruktion'. Inspirationen fra Derrida er ikke til at tage fejl af. ${ }^{8}$ Men bag ved Derrida og hans angreb på logocentrismen, dvs. den vestlige verdens traditionelle tiltro til fornuftens og tegnets repræsentation af virkeligheden, står også Heidegger og dennes modsvar til det, han kaldte metafysikkens 'værensglemsel'. Heideggers skelsættende bidrag til filosofien var at genåbne spørgsmålet om væren. Distinktionen mellem en platonisk uforanderlig væren, der i kristendommen blev fortolket som Guds væsen, på den ene side, og en verden af det foranderligt værende, verdens genstandskarakter, på den anden side, endte med at afkoble en teologisk troshorisont fra en naturvidenskabelig erkendelse, der alene havde øje for rene, men betydningstomme fænomener. Det værendes væren var lukket ud af verden og blev en tom forudsætning, som hverken filosofi eller videnskab vidste at stille noget op med. ${ }^{9}$ For imidlertid at forstå vores egen forståelse af det værende, og grunden til, at denne forståelse har udartet sig til forestillingen om en virkelighed af ydre genstande, må der atter stilles skarpt på de værensforudsætninger, hvormed vi stiller et spørgsmål til det værende. For Heidegger betød det bl.a., at tidligere tænkeres værker måtte læses med en 'destruktion' af deres eksplicitte hensigt for øje. Hans version af mistankens hermeneutik bestod med andre ord i at lade værens 'egen' betydning træde frem bagom ryggen på de tænkere, der havde fortrængt den.

Den subtile, men alligevel nævneværdige forskel, mellem Heidegger og Derrida på den ene side, og Nancy på den anden, er, at det ifølge sidstnævnte er kristendommen selv, der har gennemløbet den betydningsmæssige selvafvikling (2010, 36 f), som henholdsvis Heidegger og Derrida vil hente ud af en påført 'destruktion' og 'dekonstruktion'. Hvor Heidegger i et interview fra 1966 (bragt i Das Spiegel), henviste til, at 'kun en kommende Gud kan frelse os', og hvor Derridas begreb om nærværets, og betydningens udsættelse, først og fremmest har jødisk-messianske konnotationer, forbliver Nancy inden for en kristen tiltalehorisont. Ganske vist henviser han til Kristus som Messias forstået som navnet på en væren, en præsens, der har vist sig og som skal vise sig på ny. Men salvningen som Messias indebærer ikke i en kristen kontekst, at Jesus skal komme igen for at etablere et jødisk kongedømme

8 Selvom Derridas og Nancys tænkning gensidigt har befrugtet hinanden gennem årene, er der dog langt fra tale om samstemmighed. Således har Aleskandar Miljatović påvist, at Nancy ikke slår følge med den eskatologiske dimension, Derridas begreb om 'forskelsætten' indeholder, nemlig anticipationen af den Andens udsatte, men finale kommen-én-i-møde (2010, 3 ff). Tværtimod peger Nancy på, at den distinktion, der sætter en forskel, ikke kun udsætter den ene side af forskellen (betydningen, Den Anden) for afstand, men at 'det forskelssatte' også selv udsættes for forskellen, hvormed denne ophæver sig selv (ibid. 6). Sagt på en anden måde: Distinktionen $i$ en person, som dennes berøring med sig selv afstedkommer, fører til distinktionens ophævelse $u$ den at falde tilbage $i$ selvet selv. Dermed er 'Den Anden', hvis forskellighed (eller 'alteritet'), Derrida vil bevare, ikke trukket tilbage 'i det samme' hos Nancy, men heller ikke fastholdt i en transcendent eller selvstændig alteritet. 'Uden denne dobbelte eksponering (eller udsætten-sig-for-hinanden) kunne der ikke eksistere et uendeligt ikke-Jeg, som Jeg'et ville kunne ofre eller love sig selv til; der kunne ikke være nogen anden, som Jeg'et ville kunne være uendeligt ansvarlig over for' (ibid. 6).

9 Tværtimod er videnskabens 'kolde blik' (de sens frois), som Nancy påpeger, nødvendigt for dens adgang til verden, selvom det betyder, at den må tage en mangel på sensitivitet (over for 'mening', sens) med i købet $(1993,80)$. 
(op.cit. 56 f). Den helleniserede Kristus er forkyndelsen af en allerede fuldbyrdet, men samtidig udskudt, væren, som ikke er af denne verden, og som dog ikke er andet end denne verdens væren. Nancy kan således, i tråd med Heideggers forsøg på at vække værensspørgsmålet til live igen, forstå 'forløseren' som den, der 'redder mennesket fra Gud, fra den mumificerede død i betydningens mausoleum' (op.cit. 79). 'Gud' og 'betydning' er metafysikkens to søjler, som derfor også må falde med den.

Men i hvilken forstand kan Nancy da forestille sig den fortsatte betydning af 'Gud' og 'betydningens betydning'? Gør han sig ikke skyld i en contradicto in adjecto, når han henviser til at navnet 'Gud' stadig findes, og at håbet om betydning fortsat gør sig gældende? Det er klart, at han tænker på grænsen til det uudsigelige; men det ville være en misforståelse af begrebet om nihilisme (hos såvel Nietzsche som Nancy selv) at forstå det som en stedfortrædende ontologi. Hvis nihilisme, tabet af al betydning og al værdi, forstås absolut, ophæver det uundgåeligt sig selv. Nihilismen kan kun være en tilstand, en tømning, der ledsages af muligheden for en genkomst, en parousia i (eller af) 'tidens fylde'. I kristendommen er denne mulighed repræsenteret ved 'troen' og 'håbet'. Det betyder ikke, at nihilismen er ophævet. Tværtimod: 'den lukker præsensen og værdien af Gud op, bryder den betydning af frelse op, som består i en flugt fra verden, sletter al værdi indskrevet i en himmel, sletter himlen selv, og efterlader verden intakt og berørt af et mærkeligt gabende hul, som er nåde og sår på samme tid' (op.cit. 78). Heri består den modernitetserfaring, som for Nancy betyder, at kristendommen stadig kan tale til os. På den ene side indebærer den en 'inderliggørelse', som han først og fremmest knytter til Nietzsches 'kristne' selverfaring, nemlig at en verden af genstande og kendsgerninger forbliver tavs og værdiløs; på den anden side betyder det værensbegreb, Nancy (mere eller mindre gennem Derrida) overtager fra Heidegger, at der i menneskets blotte eksistens åbner sig en ny fylde. ${ }^{10}$ Denne fylde består netop i erfaringen af, at en såret væren, der skimter sig selv bag den blinde livsviljes umulige mål, kan tage imod nåden. I mødet med den uforudsigelighed, som består i denne erfarings egen fortsatte begivenhed eller 'finden-sted' (s'évenir), møder den intet andet end sig selv. Men netop denne 'finden-sted' "åbner i verden selv en yderside, som ikke er en uden-for-verden, men verdens sandhed" (op.cit. 79).

Nancy bevæger sig tydeligt nok i omegnen af et begreb om 'immanent transcendens', der af Deleuze og Guattari er set som et skelsættende træk ved moderne tænkning (1991, 70). Dog er begrebet hos Nancy tømt for den positivitet, som har

10 Som Nancy formulerer det: 'Eksistensen er eksponeret [exposé] - den er selve denne eksponering [exposition] - ikke for den risiko, der kommer udefra [du dehors] (eksistensen er allerede udvendig [dehors], den er at-være-udenfor [l'être-au-dehors], ikke ved at begive sig ud i det fremmedes element [l'élément étranger], (den er allerede en væren-fremmed [l'être-étranger], eller fremmedgjort [étrangé ]), som i den hegelske bevidstheds form (der også har bidraget vores endeligheds moderne historie): den er eksponeret for og af det "eks", den er, eksponeret for og af denne essensens udmattelse [défaillance], som er ældre og mere stædig end nogen tilvejebringelse af essensen [constitution d'essence], og som tilvejebringer [constitue] eksistensens selv, dvs. som kastet mod verden' (1993, 56). 
været kendetegnende for teologer og eksistentialistiske tænkere. ${ }^{11}$ Som modbegreb til den tømning, hvormed kenosis ${ }^{12}$ og repræsentation (eller 'betydningens' betydning) deler skæbne, taler Nancy om fylde, 'opfyldning', og 'en strømmen over'. Således kan vi fx erfare en 'overstrømmende finden sted' i den fylde, der 'udgydes i kunst, eller kærlighed, og som derefter løber tilbage igen' $(2010,125)$, som en tanke på det, der ikke lader sig tænke, en glæde ved at erfare, at man står over for noget altid større. 'Strømmen-over', pointerer han, består ikke nødvendigvis i en fravigelse af det overstrømmendes egen form (eller natur), men kan blot udgøre en umålelig overskridelse, 'som vand, der - idet det fylder en kop til randen - former en bule, en tynd konvergent menisk, som løfter sig over kanten på glasset' (ibid.).

\section{Gud som betydningen, der passerer forbi}

For Nancy kan transcendens alene tænkes som bevægelse, som overskriden, ikke som noget, hvortil der overskrides. Igen refererer han til Heidegger, og igen gør han det via Derrida. I sit oplæg til et filosofisk seminar om religion i en moderne verden (afholdt på Capri i 1994), henviste Derrida således til Heideggers begreb om 'en sidste Gud' som et 'vink' (Wink) om noget forbigående $(1998,55)$. Den sidste Guds væsen ligger 'i tilskikkelsen og udeblivelsen af en ankomst', siger Heidegger, 'såvel som i flugten af de daværende guder og deres skjulte forvandling' $(2003,409)$. Guderne har trukket sig tilbage fra en verden af blotte genstande og kendsgerninger, og intet tyder på, at deres forvandling igen vil antage en umiddelbart genkendelig form (ibid.). Derridas henstilling til jøder og kristne om at forholde sig til det vilkår, der annoncerer en afsked med de gamles Gud, udgør en oplagt mellemstation til Nancys perspektiv. Når Nancy tænker afviklingen af transcendensen sammen med håbet om parousiaen, betyder det ikke, at han forstår forløserens genkomst som revitaliseringen af en glemt meningssammenhæng, men derimod som en på én gang såret og åbnet væren, hvor eksistensen selv får fylde, fordi den leves i troen på og håbet om en meningstotalitet, der inde fra verden selv åbner dens yderside.

Heidegger $(2003,410)$ selv taler om 'vinket' som begivenhed eller tilskikkelse (Ereignis), dvs. som en værenshændelse, der stiller det værende i den yderste værensforladthed og samtidig gennemlyser værens sandhed indefra. Dette svarer umisforståeligt til 'verdens sandhed', som Nancy gør til parousiaens indbegreb, nemlig en genåbning af verden som betydningstotalitet. Selvom Nancy således knytter direkte til ved Heideggers begreber om 'Sein' (être) og 'Ereignis' (i form af s'évenir), foretager han ikke desto mindre en forskydning fra en absolut væren, i hvilken det historiske kan fremtræde, til en historisk og traditionsbestemt væren,

11 Nancy, der lægger sig i umiddelbar forlængelse af Deleuzes og Guattaris syn på radikal immanens, henviser til det misforståelige begreb om 'immanensens transcendens', som måske snarere burde betegnes 'transimmanens' eller slet og ret 'eksistens og eksponering' $(1993,91)$.

12 Kenosis, Guds udtømning i Kristus, er fx af Gianni Vattimo gjort til et afgørende begreb for fortolkningens fortsatte åbenhed og mangfoldighed i en vestlig kristen tradition, se fx 1997, 48-50. Det er denne positive tiltro til fortolkningens mulighed, der ifølge Nancy har mistet troværdighed. 
der udgør vores verden. Han giver med andre ord agt på sin egen værens berøring med en verden, hvori forkyndelsen stadig lyder. Men at høre denne forkyndelse er samtidig, og heri forbliver han inden for den tankefigur Heidegger har åbnet, at forstå et vink, nemlig et vink om, at den væren (eller præsens), der kommer igen, ikke er den væren (eller præsens), vi har forladt. Nancy drager dertil en yderligere konsekvens. 'Vinkets privilegium', skriver han, 'består kort sagt i det forhold, at dets betydning gives ud i den passage, som straks stjæles tilbage, i den pludseligt skjulte antydning af en betydning, som forsvinder og hvis sandhed består i denne forsvinden' $(2008,108)$. Adgangen til den væren, som det ontologiske bevis tidligere tilskrev Gud, lukkes lige så hurtigt, som den åbnes. Det er derfor ikke Gud, eller Guds væren, der passerer os i vinket - det øjeblik, hvori verden åbner sig i alteritet men Gud er vinket selv, intet andet end det passerendes egen passerende væren, som 'en gestus i retning af det værendes uindtagelige [inappropriable] væren' (op.cit. 114; 2005, 169). Ganske vist vedkender Heidegger sig en lignende 'uindtagelighed' alene ved at gennemstrege begrebet 'væren' (dvs. Seyn), endog i den allermest lokalt-sproglige form som Seyn. For Nancy drejer tænkning sig imidlertid ikke om at komme sine egne begrebslige begrænsninger i forkøbet. ${ }^{13}$ I stedet for som Heidegger at ville 'lytte' til - og grunde over - det, der tilsiges os gennem sproget, som en grundliggende betingelse for vores væren som dødelige væsner, læner Nancy sig imod den temporale berøring af en yderside (hvilket for den sags skyld ligger i selve hans begreb om, hvad berøring er, nemlig mødet med en yderside, der er i bevægelse). Ydersiden tilhører, i den verden, som en kristen kultur har formet, en gennem århundreder indhegnet verden, som det atter er muligt for en 'kristen' alteritet at lukke op. Men det, der skal komme igen, som fornyelse, som den totalitet, der på én gang realiseres som eksistens, betydning og verden, kan kun komme som et vink, som noget, der passerer forbi.

Dette begreb om vinket, som Nancy via Heidegger og Derrida knytter til et forbigående nærvær, kunne umiddelbart synes at have en vis parallel i Kierkegaards begreb om øjeblikket. Forbindelsen bekræftes endvidere af, at Nancy taler om tro som praksis. Vinket er ikke en tankes indfald, eller en vision af noget guddommeligt, men 'det religiøse' som praktisk erfaring, som en handling, der under endelighedens vilkår forholder sig til verden, som om den ikke var af denne verden. ${ }^{14}$ Dog må man samtidig fremhæve som en væsensforskel, at den alteritet, som troen tager imod - hos Kierkegaard - ikke ledsages af en dekonstrueret forkyndelse, men tværtimod af en evangelisk opbyggelighed. Hvor meget samtidens konkrete prægning spiller ind i den forbindelse, må her forblive et åbent spørgsmål.

13 Ikke alle vil finde denne implicit kontrasterende bestemmelse af Heideggers position rimelig; men det er ikke en sag, jeg kan tage op her. Se dog Nancys kritik $(1993,38)$ af den sene Heideggers divinatorisk-profetiske præsentation af sandheden.

14 En tankeforbindelse kan ligeledes spores, vil jeg mene, til en beslægtet fransk filosof Alain Badious begreb om mennesket som et udødeligt væsen (2007, 25 f.). Hermed sigter Badiou til den evne hvormed mennesket i modsætning til dyret kan handle for at opnå noget, der rækker ud over dets eget liv. 


\section{Nancys religionsbegreb}

Vi er nu nået frem til Nancys generelle begreb om religion. Selvom det specifikt er kristendommen, han forholder sig til (fordi det er den, han direkte berøres af), taler han også i mere generelle begreber om 'det guddommelige' som en distinction, en spaltning i verden. Således hæfter han sig bl.a. ved det latinske ord for 'gud', divus/deus, som samtidig konnoterer det lys, der bringer dagen. ${ }^{15}$ Med diva som den tilsvarende gudinde, 'himlens og jordens moder', følger således ikke blot verdens deling, men også lysets deling mellem nat og dag $(2008,118 ; 2010,70)$. Det guddommeliges princip er med andre ord 'den deling, som gør tingenes orden mulig' samt deres iboende relation til 'himlens ikke-ting'. ${ }^{16}$ Den ordensskabende deling, der her fremstår som et universelt princip, får imidlertid sin specifikke form i kristendommen, hvor Guds tømning (kenosis) af sig selv i verden og menneskesønnen (Kristus) resulterer i delingen mellem lys og skygge, mellem 'det at se' og det synlige. Men hvorledes, spørger Nancy (med Granel, der står fremmed over for enhver overleveret pietet), forholder vi os til den hulning, en udtømt Gud har efterladt? 'Hvordan rører vi, eller lader os berøre af, verdens åbning?' $(2008,73)$.

Nancy har dermed trukket den generelle spørgehorisont tilbage i en kristen kontekst; men med det svar, han forestiller sig, udfoldes samtidig et religionsbegreb, der rækker videre. Han henviser således til 'en gestus eller en handling' - med andre ord: en religiøs praksis - der hverken følger 'objektiveringens eller subjektiveringens' bevægelse (dvs. hverken den videnskabelige erkendelse eller den subjektive forestillingsverden), men derimod troens. 'Tro' forstås vel at mærke her som en ubetinget forholden-sig til verdens 'mærkelighed' (étrangeté), ${ }^{17}$ en mærkelighed, som selv ateisten må sande, nemlig dette forunderlige, at en deling kommer til syne, som ikke blot skaber den verden, vi mærker os, men tillige dens alteritet (der kun lader sig afmærke symbolsk). At erfare denne skelnen er at erfare tilsynekomsten af en guddommelig krop $(2008,73)$.

Umiddelbart synes der ikke at være meget at hente i dette religionsbegreb, som ikke allerede ligger foregrebet i og med strukturalismens synsvinkel. Som Claude Lévi-Strauss, til hvem Nancy selv henviser (2010, 47), har demonstreret, vidner de

15 Jeg tillader mig at tilføje den metaforiske betydning af sub divum rapere aliquid, nemlig 'at bringe noget [skjult] for dagens lys'.

16 Formuleringen stammer fra Nancys lærer, den katolske filosof Gérard Granel (Nancy 2008, 72). Det er vanskeligt at vide, hvor bogstaveligt 'ikke-ting' skal tages, men man fristes til at nævne Augustins formulering i Confessiones, som rettet mod den manikæiske materialisme anholder den fejltagelse, han selv i sin ungdom havde gjort sig skyld i ved at spørge til himlens engle og ånder, 'som om de var legemer' (quasi corpora essent, Conf.7.5). Dermed var han nemlig ude af stand til at tænke sand transcendens (Conf.7.1.2). Den betydningstømning, som i sidste ende åbner verden for andet end sig selv - i verden selv - er måske netop, som Nancy ser det, den dualitet (modsat dualisme), som har skabt en flænge, et sår, i væren (modsat dualismens endnu mytiske enhed, hvor det gode og det onde, himmelsk og jordisk, i sidste ende tilhører samme orden. Den afgørende deling, der gør religion til religion i Nancys forstand, er altså ikke foretaget i manikæisme og gnosticisme).

17 Med begrebet étrangeté spiller Nancy både på betydningen 'mærkelighed, ejendommelighed' og 'fremmedartethed, fremmedhed'. Han kan således også tale om 'mærkeligheden selv, i absolut forstand: det reales mærkelighed' $(2010,50)$. 
forskellige kulturers klassifikationssystemer gennem sprog, slægtskabsrelationer, fortælletraditioner og alimentære koder om menneskeåndens strukturerende kreativitet. Nancys tanke, nemlig at verdens guddommelighed viser sig gennem en første deling, mellem lys og skygge, synes vel blot at angive en mulig spire til fortsatte forgreninger, som i sidste ende, dvs. som kulturer, bliver til klassifikationskomplekser af interne relationer. Spørgsmålet er dermed også, om den kritik, der fra hermeneutisk side er blevet rejst over for strukturalismen (Ricoeur 1999, 255), nemlig at den forudsætter en fortolkning af de betydninger, den alene vil aflede analytisk af formale strukturer, ikke også rammer Nancy?

For Nancy er der imidlertid hverken tale om en analytisk udpegning af formale strukturer eller om en betydningsfunderet fortolkningsakt, svarende til at hans begreb om 'tro' hverken udtrykker en objektiverende eller en subjektiverende bevægelse. For Nancy er religion, i lighed med tænkningen, en praksis, der lader sig berøre af noget, som uden for den selv åbner den indefra. Den deling i verden, som kommer til udtryk i munkens bøn, og som filosoffen giver agt på, er ikke en objektiv sprække i virkeligheden, men en tilsynekomst i forbindelsen mellem tanke og handling, en måde at være - dvs. bevxge sig - i verden på. Men er dette ikke netop strukturalismens grundtanke? Uanset hvad man måtte mene om dette, adskiller den distinktion, Nancy har i tankerne, sig fra opfattelsen af strukturer som empiriske referencer (jf. Kauppert 2008), der fx kan tages til indtægt for den menneskelige hjernes biologiske spor. ${ }^{18}$ Delingen (der alt andet lige ligger tættere på Hegels begreb om spaltning, Entzweiung) kan alene forstås som spor af en erfaring, som en umiddelbart lyttende, berørt, røren ved verden. Af samme grund er religion ikke et fænomen, filosofien kan tilgå objektivt. Berøres tænkningen ikke af religionen, skulle den hellere lade den være. Men at mennesket, og måske det moderne menneske i særdeleshed, indser sin egen endelighed som en væren-i-verden (in-der-Welt-sein) og en væren-indtil-døden (Sein-zum-Tode), som Heidegger har formuleret det (1993), indebærer så meget desto mere tanken om 'det uendelige'. Endeligheden, siger Nancy, viser sig netop som uendelighedens åbning. 'Det vi kalder for 'endelighed" - dødelighed, natalitet, tilfældighed - ville ikke eksistere, hvis ikke vi i selve dets benævnelse [le nommons] tillod det at angive, at vi eksisterer og at verden eksisterer som en åbning til det uendelige eller via det uendelige' $(2010,11)$. I den græske filosofi fandt denne åbning sit udtryk i distinktionen mellem det værende (det endelige) og væren som sådan (det uendelige). I religionen, herunder kristendommen, materialiserede den sig i et struktureret kosmos centreret omkring en verdensskabende alteritet. Men det var to sider af samme sag, genkendelig som den deling, der skiller ordet fra dets genstand, det indre fra det ydre, og som efterlader sig en intethed, kun troen og håbet kan fylde. Man kan hævde, at Nancy dermed siger meget lidt om religion og i stedet noget om, hvorledes en opfattelse af verden og dennesidig-

18 Der er her tale om en tentativ hypotese, Lévi-Strauss undertiden har givet udtryk for i interviews; se endvidere Lévi-Strauss 1994, 141; 246ff. Lévi-Strauss er endog gået endnu videre og taler om strukturer som selve materiens grundprincip, se RvT 4, 1984, $121 \mathrm{f}$. 
hed overhovedet lader sig tænke. Men hans pointe er netop, at det ene ikke kan siges uden det andet.

\section{Tilbedelse: fra frelse til hilsen}

Nancy ser først og fremmest religion som en praksis, der ved at forholde sig til en deling, en alteriet midt i verden, finder sted som tilbedelse. Tilbedelse er, som ordet ad-oration siger, en til-tale, en henvenden sig til en anden, eller noget andet, der dermed åbner den, man selv er, og det sted, man selv står $(2010,18)$. At tilbede er at underkaste sig en magt, i forhold til hvilken ens egen væren tager form. Hvis den magt, tilbedelsen besværger i monoteismen (og Nancy medtænker i den forbindelse Buddhismen), først og fremmest selv giver sig til kende som tiltale, dvs. som ord eller som ordets magt -, betyder det, ifølge Nancy, at det er ordet, og i videre forstand sproget, der 'i Gud' har overtaget offerritualets effektivitet. Hvor blodet, herunder 'det i kulten udgydte blod', som Nancy formulerer det, skaber bånd mellem mennesker, skaber ordet en åbning i livet selv, såvel for den levende som for verden (op.cit. 6). Men samtidig udtømmer denne åbenhed den væren, i hvis navn den er udtalt. Alteriteten kan ikke gives et navn, eftersom den overskrider al navngivning (à nommer). 'Der gives intet tilknytningspunkt [joindre] til den; den former selve udsagnets sammenføjning [jointure] og tilslutning [jonction], selve betydningens uendelige mulighed' (ibid., 15).

På den ene side forekommer der her klare associationer til negativ teologi, måske ovenikøbet spor af kabbalistisk mystik; på den anden side genkendes selve tankefiguren i det paradoks, Wittgenstein lancerede med Tractatus Logico-Philosophicus, nemlig at det sprog, vi bruger til at afbilde verden med, ikke kan redegøre for de præmisser, der gør dette muligt. Hvis verden, som i Tractatus, lader sig beskrive som 'alt det, der er tilfældet', må selve meningen (Sinn) med dette, dvs. med verden, ligge uden for verden selv (TLP 6.41). I Nancys terminologi betyder det, at den overskridelse af navnet og ordet selv, der ligger til grund for 'den sammenføjning', de udtrykker ved sig selv, er den 'strømmen-over', eller 'fylden-op', som kun anes i den skrøbelige skælven, selve relationen udgør som relation (rapport). Og her knytter Nancy så direkte til ved Wittgenstein: Denne skrøbelighed er den 'mening med verden', skriver han, som 'må ligge uden for verden' (2010, 125 med henvisning til TLP 6.41 i note 2$){ }^{19}$

19 Tilsyneladende tager Nancy denne tilslutning Tractatus tilbage igen, når han andetsteds om 'verdens betydning' (le sens du monde) bemærker, at det ikke drejer sig om en betegnelse af det faktisk givne, hvilket nemlig - med Tractatus - ville have ført til det paradoks, at 'verden' som betydning måtte transcendere denne givethed $(1993,90)$. I stedet fremhæver han Spinoza som 'verdens' første tænker i den forstand, at Spinoza med sin parole deus sive natura forstod, at verden, som den er, 'har sin yderside på indersiden' - at det, der i verden viser udover verden selv, er verden selv. Dette er imidlertid en oplagt parallel til Wittgensteins spinozistisk inspirerede pointe i Tractatus og ligger umiddelbart i forlængelse af den måde, hvorpå Nancy i øvrigt refererer til denne (som ovenfor nævnt, 2010, 125). 
Igen er Nancys pointe, at den filosofiske og den religiøse tanke ikke står fremmede over for hinanden, men kommer hinanden i møde, idet de berøres af et fælles punkt, en fælles åbning. 'Adskillelse, distinktion, åbning - relation', skriver han opremsende: 'vi må lære at tyde hvordan det [religiøse] mysterium er selve relationens mysterium' (2010, 70). Trinitaritetens mysterium er fx, at al betydning er relation, relation som relation, hvilket netop betyder, at verdens yderside viser sig inden for verden uden at være $a f$ denne verden (op.cit. 77). Men også et andet mysterium følger af dette: den 'gud', der allerede ved sig selv har undsagt sin væren har dermed også omstødt sin egen adskillelse fra menneskeheden, netop ved at blive kød. Det, der således bliver tilbage, eller som atter åbner sig, af fantasmerne 'inkarnation' og 'genopstandelse', stammer fra en tid, hvor verden allerede var denne verden, hvor alteriteten ikke længere var mytens eller erstatningsofrets alteriet, men denne verdens alteritet, legemliggjort gennem menneskesønnen. Begreberne 'inkarnation' og 'genopstandelse' siger ikke andet end:

at det er op til os mennesker, vi dødelige, som er uden Gud og uden natur, at give mening [de faire sens] til denne 'vores' verden, hvis uendelige [indéfini] produktion, vi som teknikere er beskæftiget med. Men eftersom mening ikke er 'fremstillet' [ne se 'fait' pas], ikke er produceret, tilfalder det os i stedet at erkende, hvorledes den overhovedet kommer til syne [avoir lieu] $(2010,77) .{ }^{20}$

Mening eller Betydning (sens) er relation, det at stå - eller rettere passere - i forhold til noget andet end sig selv, hvormed man overhovedet kan være den, man er. Og samtidig er relationen 'betydningens pulseren, en kommen og gåen fra én til en anden, fra nogle til andre, uden at etablere nogen anden værenskontinuitet [continuité d'être] end rytmen af vores samvær [commune présence], vores sam-tilsyne-komst [comparution] og gensidige eksponering [exposition]' (2010, 92). Man kan drage en forsigtig parallel til den rytmik, som ritualforskeren Roy Rappaport fx forbinder med sang- og danseritualer, hvor en synkronisering af deltagernes åndedræt og hjerterytmer synes at forene de enkelte medlemmer til en større, levende organisme $(1999,363),{ }^{21}$ og netop den fysisk-praktiske form, enhver tilbedende relation antager, har Nancy selv i tankerne med sit valg af ordene puls og rytme. Tæt associeret hermed er således den puls, der i samlejet udgør en værensrytme, som er sin egen kommende og gående betydnings betydning. Men netop det flygtige, det forbigående, det umulige $i$ at fastholde den alteritet, som relationen fremmaner, er først og fremmest det, der her optager Nancy. Den sandhed, som verdens deling åbner for,

20 Som Nancy også skriver: 'Verdens væren er en betydningens væren - og sådan forholder det sig enten i sig selv eller gennem os, hvilket i sidste ende er et og det samme, eftersom vi selv er af denne verden men også det, som i verden åbner sig som dens yderside, en yderside som alene giver verden dens sandt 'verdslige' dimension: relationens mulighed, kraft, og dynamik' (op.cit. 90).

21 Som Rappaport videre skriver: "To sing with others, to move as they move in the performance of a ritual, is not merely to symbolize union. It is in and of itself to reunite in the reproduction of a larger order. Unison does not merely symbolize that order but indicates it and its acceptance. The participants do not simply communicate to each other about that order but commune with each other within it" $(1999,220)$. Rappaport har, så vidt jeg kan vurdere, udtrykt en pointe, der ligger tæt på Nancys, når han påpeger, at fællesskabet ikke symboliseres af en rytmisk harmonisering medlemmerne imellem, men er selve denne relations form eller udtryk. 
er ikke tilskrivningen af betydning (signification), men den mening, der ligger i selve adorationen forstået som hilsen (salut). Håbet om frelse (ligeledes salut på fransk) ${ }^{22}$ har således fra begyndelsen af været adorationens respons på en hilsen fra Gud og har i relation hertil sigtet på udfrielsen af en verden, der alene bekymrede sig - og lukkede sig - om sig selv. Det er denne lukkethed, eller indhegning (clôture), som i dag bærer resterne af fornuftens og tegnets tømte betydninger med sig. Den moderne verdens 'frelse' (salut) består således ikke i genoplivelsen af verden som tegn for det værendes betydning, men af verden og eksistens som betydning (sens), som den uendelige, ubestemte og udsatte, mulighed for betydning, eller slet og ret: den passerende 'hilsen' (salut). 'Sandheden er ikke en væren', som Nancy skriver, 'og stammer ikke fra væren, men er sand eksistens' (op.cit. 92). Hvad er da 'sand eksistens'? Sand eksistens er uløseligt forbundet med Navnet, den unævnelige Guds navn, hvormed enhver hilsen viser tilbage til tilbedelsens rod, en passerende hilsen (salut) fra Gud (der bestandigt udtømmer sig i det forbipasserende øjeblik), men også den respons, der ligger i enhver tiltrækning, begær, lyst (ibid.). ${ }^{23}$ 'Simpelthen at relatere til hinanden, simpelthen at navngive hinanden [les nommer] og at skimte hinanden $\mathrm{i}$ forbifarten, i denne verden, og denne verden selv som en passeren mellem intet og intet' (op.cit. 93). Enhver tilbedelse må således 'passere gennem navnet [en nommant], som er en hilsen til det unævnelige [l'innommable], ethvert navn [le nom] skjuler i sig, og som ikke er andet end denne verdens tilfældighed' (ibid.).

Man spørger uvægerligt sig selv, om Nancy ikke dermed har skrevet sig tilbage i den nihilisme, som dannede grundlag for en gentænkning af den kristne forkyndelse. Men Nancys pointe er ikke en overvindelse af nihilismen. Tværtimod beror sandheden i den blotte eksistens på, at intetheden atter skaber rum for betydningens mulighed, omend i en form der alene finder sted som et vink, en hilsen, en forbipasseren - som en antydning af, eller et håb om, den totalitet, der uden at være af denne verden skal forløse den. Vores sprog vidner om denne iboende guddommelighed, for så vidt som det kommer 'udefra' og vender tilbage til sig selv, nemlig ved at vende 'sig mod den yderside som det selv åbner i os, ved at åbne vore munde, og ved at åbne dette mærkelige/fremmede [étrange] tegn 'menneske', i midten af verden' (2010, 101). Det betyder bl.a. at 'guderne' helt igennem selv er sprog, 'de er navne, myter, tilråb [des appels]' (ibid.). Monoteismens (og på en særlig måde Buddhismens) gud er en gud, der taler, og i denne tale udslettes 'gud' selv, bliver unævnelig.

Igen anslår Nancy en Wittgensteiniansk tone, når han drager den konsekvens, at tilbedelsen (adorationen forstået som en 'sig selv underkastende tiltale') alene forholder sig til den åbning, som den selv skaber gennem sin blotte ek-sistens (2010, $103 \mathrm{f}$ ), hvorfor dens tilfredsstillelse allerede indbefattes af 'dens egen bevægelse, dens eget begær' (op.cit. 123). Det svarer til troen, som ikke er tro ved at stå i forhold

22 Nancy spiller klart nok på den sproglige forbindelse mellem det lantiske salus (frelse) og saluto (hilser eller: bringer en hilsen fra en anden). Nancy vil således koble det kristne begreb om frelse til den hilsen, Kristus bringer fra Gud.

23 Nancy $(1993,85 f)$ knytter ligeledes spørgsmålet om mening til begærets imødekommende bevægelse: 'Betydning [sens] er den reciprokke og uforbeholdne væren-over-for begærets anden og gaven'. 
til en betydning, en væren (et 'korrelerende objekt'), uden for sig selv, men alene ved en tilslutning (adhésion) til sig selv. I selve dette formål ligger troens meningsopfyldelse (eller betydningsfylde, remplissement de sens, 2005, 221). Til sammenligning skriver Wittgenstein i sine bemærkninger til Frazer, at den rituelle fremstilling af et ønske (som fx i magisk praksis) allerede, eo ipse, rummer sin egen opfyldelses fremstilling $(1993,125)$. Hvor Wittgenstein vil sige, at man må forstå den grammatik, ${ }^{24}$ som bønnen og tilbedelsen benytter sig af, for at forstå, hvorfor det begreb om reference, der følger af grammatikken for empiriske kendsgerninger, ikke hører hjemme her, formulerer Nancy sig på den måde, at den uendelige distance, som tilbedelsen er rettet imod, aldrig kan være en ting eller noget værende, men derimod en distance, der relaterer sig til sprogets egen grænse $(2010,101)$. Men den tale (eller tiltale), som taler udover sig selv, hinsides sproget, taler ikke om 'det hinsidige' (audelà): 'den taler hinsidigt' (elle parle au-delà) (ibid.)!

For at gøre os et klarere begreb om, hvad Nancy mener med dette, må vi knytte en forbindelse tilbage til Heidegger. Denne forbindelse træder frem, når Nancy til sit begreb om 'det transcendente' føjer, at talen - dvs. tilbedelsen og tilsigelsen, nemlig det religiøse sprog, hvori guden og mennesket spejler sig i hinanden - skaber verden ved at relatere dens eksistenser (étants) til den grund (eller med Heideggers begreb 'afgrund', Abgrund) af intet (nihil, med Heidegger: Nichts), som 'menneskene holder afstand til ved at forholde sig til hinanden' (ibid.). Sproget er det middel, hvormed menneskene fastholder denne relation. Men det er ikke menneskene, der skaber relationen. Den relationalitet, der gør sproget til sprog, går forud for de talende selv. 'Rent faktisk', skriver Nancy, 'modtager talen sig selv fra det hinsidige allerede før den taler' (ibid.). Men betyder det hinsidige så det, hvortil talen angiveligt refererer? Nej, netop ikke. Det betyder derimod, at talen altid allerede er givet. Den er 'tilsagt' os gennem naturen selv, 'gennem stemmebåndet, tungen, hele det tonale apparat, ligesom den symboldannelse, der finder sted via det retikulære aktiveringssystem', dvs. strukturer i hjernestammen (ibid.). I denne absolutte immanens ser Nancy imidlertid en direkte forbindelse til mystikerens udsagn om allerede at være tiltalt, som $\mathrm{fx}$ sufisten Bayazid Bastamis udtrykker det: 'Jeg troede jeg påkaldte Ham, men Hans påkaldelse (af mig) gik forud for min egen' (ibid., 102). Tænkningen, uanset om den er religiøs eller ej, støder på samme grænse i det uudsigelige, eller, om man så må sige, det før-sigelige. For Nancy synes det hinsidige ikke at være andet end dette førsigelige, men hermed 'taler' han ikke desto mindre om en åbning, som ikke lader sig beherske af noget tegn.

Nancy sammenfatter sin tanke om forholdet mellem kristendommens og den vestlige filosofis erkendelse af dette nulpunkt, som allerede indeholder en iboende nihilisme, på følgende måde:

Vesten er uden grund (under sig); den er opfindelsen af grundens fravær [d'absence de sol] som noget oprindeligt givet [donnée], og derfor ikke engang fravær eller mangel

24 Som Wittgenstein forstår 'grammatik' spænder det fra grammatiske regler i gængs forstand til de i vores sprogbrug indlejrede regler, der er bestemmende for et udsagns betydning i en given sammenhæng ( $\mathrm{fx}$ religiøse og videnskabelige udsagn). 
[privation], men udsagn om en yderside som sandhed: ikke en sandhed 'om det indre', men en sand eksposition af det indre, en udøvelse [ex-action] og uddrivelse [extraction] af hele den principielle bevægelse $(2010,106)$.

Vi skal formentlig forstå dette som selvafvikling, nemlig den selvafvikling, der ligger i selve den relation, hvormed det gives os at forholde os til noget andet end os selv og den verden, vi lever i. Gud hilser (dvs. velsigner) os ved at passere os, ved at komme og gå, ved afvikle sig selv i den verden, hvis inderside dermed viser sig i forhold til en yderside, der ikke er af denne verden, men heller ikke andet end denne verden.

Navnet 'Gud', der har overlevet den betydning af uforanderlig væren, kristendommen engang tilskrev Gud selv, er det navn, der unævneligt står bag delingen mellem dag og nat (dies/nox), og som 'åbner verdens rytme, den generelle mulighed for distinktioner, og derfor selve relationernes og passagernes mulighed' $(2010,114)$. Så snart dette tegn, 'Gud', imidlertid begynder at dominere, og i hvis navn tilbedelsen underkaster sig, ophæves atter relationens og passagens væsen. 'Gud' bliver dermed den åbning i verden, der atter lukker den. 'Det er det, der uundgåeligt sker i alle teologiske og metafysiske bestemmelser af "Gud"' (ibid), hvorfor det formentligt er umuligt, antager Nancy videre, at noget navn overhovedet kan fastholde selve bevægelsen, passagen (le passage), det skælvende gab i væren. Konsekvensen er, siger han, at "'Gud" kun bør nævnes i forbigående [en passant], og som en forbipasserende [comme passant]' (ibid.).

Med lige nøjagtigt dette 'bør' (il faudrait) taler Nancy som filosof på vegne af teologien. Men han taler fra et sted i moderniteten, der vedkender sig ${ }^{25}$ de teologiske begrebers udtømning, fraværet af et metafysisk betydningsgrundlag. Han taler fra en position, hvor de religiøses udsagns betydning ikke falder sammen med det, de rent faktisk siger. Oversat til det spørgsmål, Heidegger stiller angående metafysikkens væsen (2004, 105 ff.), betyder det, at religionen idet den taler om - og taler til, dvs. tilbeder, alteriteten - slet og ret forholder sig til værens grund af intethed (das Nichts). Og Nancy refererer her til et forhold, der gør sig gældende i 'alle former for og alle epoker af kultur, religion og filosofi'. Blot kommer det særligt til udtryk i religionen (i generel forstand) ved at denne i sprog og praksis 'udfylder intetheden [remplit le rien]' $(2010,26)$. For at forstå dette udsagn som udtryk for andet end religionskritikkens fortærskede udsagn om religiøse forestillingers illusoriske karakter (som trøst, erstatning, livsløgn), må man huske på Nancys billede af vandspejlet, der hæver sig i en let bue over glassets kant. Ved at udfylde intetheden, hæver væren sig $\mathrm{i}$ et såret og skrøbeligt, men ikke desto mindre sandt nærvær, der overskrider verden uden at forlade den.

Nancys specifikke interesse for kristendommen til trods, og hans forsøg på som tænker at reflektere over grunden til, at denne 'religion' som kulturtradition fortsat berører os i sin historiske bevægelse, taler han fra et sted og ind i en sammenhæng,

25 Egentlig forekommer det uklart, hvilken status denne 'modernitetserfaring' har (diagnosticering? hævdelse?). 
der også berører religionsvidenskaben. Spørgsmålet er, hvad Nancy og den form for religionsfilosofi, han repræsenterer, kan bidrage med i denne sammenhæng.

\section{Nancy inden for en religionsvidenskabelig spørgehorisont?}

Religionsvidenskaben orienterer sig primært inden for en kontekst af empiriske fænomener. 'Religion' antager på forhånd genstandskarakter og udelukkes derfor fra at interagere dialogisk. Det er i hvert fald den typiske grænsedragning inden for komparative religionsstudier, der skal kunne agere - og kommunikere - inden for et register af teoretiske indfaldsvinkler til religion som et historisk, kulturelt, socialt og psykologisk fænomen. Hvad vi end ud fra 3. ordensbetragtninger måtte definere som 'religion', betragtes det pågældende genstandsfelt som fænomener på lige fod med alle andre fænomener i en menneskeskabt virkelighed. Hvis dette med rimelighed kan kaldes religionsvidenskabens raison d'être, skal det straks pointeres, at religionsfilosofien uden at have noget principielt at indvende over for denne videnskabelige praksis, orienterer sig ud fra en anden indfaldsvinkel. Hvor en videnskabelig erkendelse må hvile på et grundlag, den kan bedømme sine resultater ud fra, vil filosofien typisk rette sit blik mod dette grundlag selv. Hvor den europæiske filosofi fra antikken til skolastikken støttede sig til et religiøst perspektiv og siden gav sin støtte til videnskaben (efter den kopernikanske vending), er den i moderniteten kommet i tvivl om selve grundlagets tilstedeværelse, ikke ad hoc, dvs. på de konkrete undersøgelsers og metoders vegne, men generelt, dvs. på tænkningens.

I forlængelse af Wittgenstein - og Nancys henvisning til ham - må det pointeres, at beskrivelsen af kendsgerninger ikke har samme karakter som beskrivelsen af den totalitet, de rummes inden for, og netop denne totalitet har, som Nancys gentagne gange pointerer, udtømt sig i den lukkethed, hvormed tingenes og ikke-tingenes betydning har erobret 'verden'. Men som den sene Wittgenstein siger: 'Hvis det sande er det, der har en grund, så er grunden ikke sand, ejheller falsk' (1969, 148, § 205). Såvel kristendommens som filosofiens (samt herunder en universaliserende videnskabs) kriterier for sandhed har således stillet sig på en grund, der var dømt til at skride under dem eller som med Nancys ord åbnede en yderside indefra den verden, de bestræbte sig på at beherske - eller 'indhegne' (for nu at bruge hans egen metaforik). En af de pointer, vi kan hente ud af Nancys tænkning er dermed, at hverken en empirisk bestemt tilgængelighed eller en dogmatisk bestemt hinsidighed i sidste ende kan sikre den 'betydning' (sens), de hver især appellerer til. ${ }^{26}$ I begge tilfælde er der tale om en navngivning, som bærer en uudsigelighed med sig, og som derfor står blottet tilbage som navngivning, som en adoration og en hilsen, der åbner verden. Nancy distancerer sig i den forbindelse fra den fænomenologiske reduktion af vores blotte forhold til verden (som hos Jean-Luc Marion 2002), for i ste-

26 Nancy $(1993,32)$ taler således - med henvisning til bl.a. Heidegger - om en moderne 'transcendering' af verden 'frigjort som betydningens absolutte horisont, der ikke længere er underlagt hverken en hinsidig verden [outre-montre] eller den blotte repræsentation (dvs., hverken himmel eller natur)'. 
det for at tage afsæt i Heideggers 'in-der-Welt-Sein' som udtryk for, at vi hver især er verden $(2010,102)$. Men netop fordi vi er verden, uden afstand til alt det, der fra tanke til ting indgår i den, opstår der sig samtidig en alteritet i den relation, vi adresser den med.

At ek-sistere, hvilket med Heidegger betyder 'at stå ud i væren' $(1988,36)$, er samtidig at være sig denne eksistens bevidst, og for Nancy betyder dette at hilse såvel vores egen væren som altings indbyrdes relationer velkommen - som blot og bar eksistens (ibid.). Dette er en tanke, der uden at være religiøs i traditionel forstand, uvægerligt minder om en tænkemåde, som træder os i møde fra religionernes - og måske ikke mindst mystikkens - forestillingsunivers. Det ville da heller ikke være uinteressant eller umuligt at gøre Nancys filosofi til genstand for en religionsvidenskabelig betragtning. Dog ville det tilsidesætte det spørgsmål, som det for Nancy er vigtigt at tage udgangspunkt i, nemlig fraværet af en sidste mening, eller et sidste grundlag, som $\mathrm{fx}$ et objektiverende perspektiv blindt tager for givet. Hvis tabet af mening (sens) med andre ord melder sig som 'betydningsfuldt' (hvilket i sig selv synes at være et tankevækkende paradoks), ${ }^{27}$ eller i det mindste som et vilkår, tænkningen ikke kan eller vil tilsidesætte, indebærer det, at hverken religionen eller religionsvidenskaben forsyner os med et tilstrækkeligt udsagnsrum. Det kan forekomme bagvendt, at en tilsyneladende mangel således kan pege i retning af 'noget mere'; men Nancys tanke er netop, at dette 'mere' opstår på baggrund af en verdenstillukning, som ikke længere er i stand til at holde sig selv ved lige (hverken som de interne relationer, der knytter denne verdens 'ting' til religionens 'ikke-ting', eller de ligeledes interne relationer, der alene knytter sig til videnskabens 'ting'). Med mindre hans diagnose af det betydningstab, hvormed kristendommen med sin selvafvikling har genåbnet sit eget udsagnsrum, afvises som ren spekulation, burde det måske skærpe vores blik for, at der i det forhold, religionsvidenskaben etablerer til religion, åbner sig andet og mere end et bestemt genstandsfelt. Den måde, vi er verden på, er af en anden verden $i$ verden. For en filosofisk synsmåde som Nancys gør dette forhold sig ikke blot gældende for religionen, men også for tænkningen som tænkning. Med denne genstandsløshed, eller problematisering af selve genstandsforholdet, træder en Nancy-inspireret religionsfilosofi et forsigtigt skridt ud af videnskabens tryllekreds, og er derfor noget andet end en ren teori om religion.

Wittgenstein bekendte engang over for en af sine venner, at han ikke var et religiøst menneske, men ikke desto mindre var tilbøjelig til at se ethvert problem ud fra en religiøs synsvinkel (Drury 1984, 79). Måske kunne noget tilsvarende siges om Nancy. Og muligvis siger det ikke kun noget om personlige gemytter, men også mere generelt noget om den måde, hvorpå forholdet mellem religion og filosofi på

27 Nancy $(1993,21)$ indrømmer, at 'den dialektiske risiko springer i øjnene: at uddrage ressourcen til en højere meningstilskrivning [signification] af meningstilskrivningernes [significations] tilintetgørel-

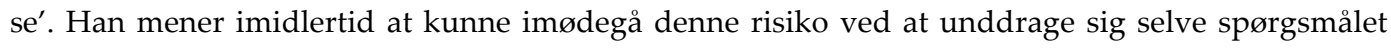
om 'meningstilskrivning' for i stedet at fokusere på den tætte (verbale) forbindelse mellem 'mening' og 'sansning' (sens). For at tydeliggøre denne forskel mellem sens og signification, har jeg undladt at oversætte sidstnævnte med det ellers mere gængse 'betydning'. 
den ene side, og filosofi og videnskab på den anden side, har udviklet sig gennem tiden.

\section{LITTERATUR}

Augustin

2000 Confessiones/Bekentnisse, Reclam.

Badiou, Alain

2007 Etikken - Et essay om erkendelsen af det onde, oversat af Holger Ross Lauritzen, Philosophia.

Deleuze, Gilles \& Felix Guattari

1991 Hvad er filosofi?, oversat af Carsten Madsen, Moderne Tænkere, Gyldendal.

Derrida, Jacques

1967 De la grammatologie, Gallimard.

1998 "Faith and Knowledge: The Two Sources of 'Religion' at the Limits of Reason Alone", in: Jacques Derrida \& Gianni Vattimo, ed., Religion, Polity Press, 1-79.

Drury, M. O'C.

1984 "Some Notes on Conversations with Wittgenstein", in: Rush Rhees, ed., Recollections of Wittgenstein, Oxford University Press, 76-96.

Foucault, Michel

1999 "Philosophy and the Death of God", in: Jeremy Carrette, ed., Religion and Culture - Michel Foucault, Routledge, 85-86.

2006 Ordene og tingene: En arkæologi om humanvidenskaberne, oversat af Mogens Chrom Jacobsen, Det Lille Forlag.

Gauchet, Marcel

1997 The Disenchantment of the World: A Political History of Religion, oversat af Oscar Burge, Princeton University Press.

Heidegger, Martin

1988 Et Brev om 'Humanismen', Akademisk Forlag.

Heidegger, Martin

1993 Sein und Zeit, Max Niemeyer Verlag.

2003 Gesamtausgabe III. Abteilung, Band 65: Beiträge zur Philosophie, Vittorio Klostermann.

2004 Wegmarken, Vittorio Klostermann.

Kauppert, Michael

2008 "Ein romantisches Gehirn - zum cerebral turn in der strukturalen Anthropologie", Berliner Journal für Soziologie 2, 307-333.

Marion, Jean-Luc

2002 Being Given. Toward a Phenomenology of Givenness, Stanford University Press.

Marx, Karl

2000 "Bidrag til kritikken af den hegelske retsfilosofi", in: De Store Tænkere, oversat af Johannes WittHansen, Rosinante, 51-66.

Miljatović, Aleksandar

2010 "Division of touch: Distinct in Jean-Luc Nancy and Jacques Derrida", Trans 17: 5.3 (Internet.Zeitschrift für Kulturwissenschaften), 1-9.

Nancy, Jean-Luc

1993 Le sens du monde, Galileé.

2005 La Déclosion: Déconstruction du christianisme, 1, Galilée.

2008 Dis-Enclosure : The Deconstruction of Christianty I, oversat af Bettina Bergo, Gabriel Malenfant \& Michael B. Smith, Fordham University Press.

2010 L'Adoration: Déconstruction du christianisme, 2, Galilée. 
Nietzsche, Friedrich

1999 Werke in drei Bänden: Band 2, in: Karl Schelchta, ed., Carl Hanser Verlag.

Rappaport, Roy

1999 Ritual and Religion in the Making of Humanity, Cambridge University Press.

Ricoeur, Paul

1999 "Hvad er en tekst?", In: Jesper Gulddal \& Martin Møller, eds., Hermeneutik - en antologi om forståelse, oversat af Laurits Lauritsen, Gyldendal, 238-262.

Vattimo, Gianni

1997 Beyond Interpretation: The Meaning of Hermeneutics for Philosophy, Polity Press.

Weber, Max

2009 "Wissenschaft als Beruf, 1917, 1919 ", Gesamtausgabe, Abt. I, Bd. 17, Siebeck Mohr.

Wittgenstein, Ludwig

1963 Tractatus logico-philosophicus, in: idem, Schriften, Suhrkamp.

1969 Om vished, oversat af Jørgen Husted, Philosophia.

1993 Philosophical Occasions 1912-1951, in: J. Klagge \& A. Nordmann, ed., Hackett Publishing Company.

Lars Albinus, lektor, dr. theol., Afdeling for Religionsvidenskab, Aarhus Universitet

lal@cas.au.dk 